DOI: https://doi.org/10.31933/jimt.v2i3

Received: 1 Desember 2020, Revised: 25 Januari 2021, Publish: 16 Februari 2021

JIMT
JURNAL ILMU MANAJEMEN
TERASTI

\title{
ANALISIS KOMPARATIF RASIO KEUANGAN PT. SUMMARECON AGUNG, TBK DENGAN INDUSTRI PROPERTY \& REAL ESTATE YANG TERDAFTAR DI BURSA EFEK INDONESIA PERIODE 2014- 2019
}

\author{
Nurfaiz Ekosetio ${ }^{1}$ \\ ${ }^{1)}$ Program Studi Magister Manajemen, Universitas Mercubuana, Jakarta, Indonesia, \\ nurfaizeks@gmail.com
}

\section{Corresponding Author: Nurfaiz Ekosetio ${ }^{1}$}

Abstrak: Dalam menjalankan perannya sebagai unit bisnis, perusahaan memerlukan penilaian kinerja sebagai evaluasi dan alat pengambilan kenijakan oleh manajemen perusahaan. Analisis laporan keuangan tahunan bsa dilakukan dengan menilai rasio rasio keuangan dari setiap pos pada laporan keuangan. Penelitian dalam karya tulis ini memaparkan perbandingan kinerja antara PT.Summarecon Agung, Tbk dengan total industrinya yang terdaftar di Bursa Efek Indonesia. Data didapatkan dengan metode dokumentasi melalui laman web perusahaan. Pengolahan data dilakukan dengan menghitung dan menganalisis rasio keuangan dan analisis Dupont. Sehingga didapatkan hasil akhir perbandingan kinerja yang dapat dikatakan bahwa kinerja antara keduanya seimbang atau hampir sama.

Kata Kunci: Analisis keuangan, laporan keuangan, rasio keuangan.

\section{PENDAHULUAN}

Dalam upaya mempertahankan keberjalanan operasional perusahaan dalam bisnisnya, diperlukan sebuah penilaian untuk mengevaluasi pencapaian dari target yang telah ditetapkan oleh perusahaan. Salah satunya penilaian keuangan perusahaan yang dilakukan guna mengetahui kinerja perusahaan tersebut. Hal tersebut bisa diukur dengan melakukan analisis dari laporan keuangan tahunan perusahaan.

Menurut Irham Fahmi (Dalam Makatita, Reyner F, 2016:2) menyebutkan bahwa kinerja keuangan adalah suatu analisis yang dilakukan untuk melihat sejauh mana suatu perusahaan telah melaksanakan dengan menggunakan aturan-aturan pelaksanaan keuangan secara baik dan benar.

Penilaian kinerja keuangan setiap perusahaan adalah berbeda-beda, tergantung kepada ruang lingkup bisnis yang dijalankan oleh perusahaan. Jika perusahaan tersebut bergerak pada sektor bisnis pertambangan maka itu berbeda dengan perusahaan yang bergerak pada bisnis pertanian serta perikanan. Maka begitu juga pada perusahan yang bergerak pada sektor keuangan seperti perbankan yang jelas memiliki ruang lingkup bisnis berbeda dengan ruang lingkup bisnis lainnya (Makatita, Reyner F, 2016:2). 
Pengukuran hasil usaha yang dicapai dapat dilakukan dengan cara menganalisis rasio keuangan, Menurut Munawir (Dalam Safriadi, Pohan, 2017:1). Penghitungan analisis rasio menggunakan data laporan keuangan perusahaan. Menurut Sutrisno (Dalam Safriadi, Pohan, 2017:1) memaparkan bahwa pada dasarnya ada beberapa rasio keuangan yang biasa digunakan yaitu rasio likuiditas, rasio solvabilitas, rasio keuntungan/profitabilitas, rasio leverage, rasio aktivitas dan rasio penilaian.

PT Summarecon Agung, Tbk adalah sebuah perusahaan yang sudah go public dan sudah terdaftar di Bursa Efek Indonesia, sehingga masyarakat umum dapat dengan mudah mengetahui kondisi dan kinerja perusahaan melalui laporan keuangan yang diunggah pada laman web perusahaan. Ranah bisnis yang dikembangkan oleh PT Summarecon Agung, Tbk adalah pada bidang industri real estate \& property. Produknya adalah pengembangan kawasan perumahan di beberapa tempat di Indonesia, salah satunya adalah kawasan hunian mandiri Summarecon Serpong dan Summarecon Bekasi.

\section{KAJIAN PUSTAKA Laporan Keuangan}

Laporan keuangan adalah laporan yang disusun oleh perusahaan sebagai alat untuk menyampaikan informasi tentang kondisi keuangan perusahaan kepada pihak pihak yang berkepentingan, seperti pihak internal perusahaan (karyawan, manajer, stakeholder), dan pihak eksternal perusahaan (supplier, bank, pemegang saham publik).

Laporan keuangan perusahaan menyajikan empat laporan keuangan dasar, di antaranya: neraca, laporan rugi laba, laporan laba ditahan dan laporan arus kas. Laporan tersebut mempresentasikan kinerja perusahaan serta posisi keuangan perusahaan pada suatu periode dalam upaya pertanggungjawaban pengelola perusahaan agar para pihak dapat menganalisis dan melakukan penilaian serta mengambil keputusan untuk kelanjutan program kerja perusahaan.

\section{Rasio Keuangan}

Rasio keuangan merupakan pengolahan angka perbandingan rasio dari data laporan keuangan satu dengan yang lain. Angka perbeandingan tersebut dapat mempresentasikan apakah kondisi keuangan suatu perusahaan sehat atau tidak. Laporan keuangan perusahaan mempresentasikan kinerja perusahaan, posisi keuangamm saat tertentu, serta arus kas perusahaan pada suatu periode dalam upaya pertanggungjawaban pengelola perusahaan agar para pihak dapat menganalisis dan melakukan penilaian serta mengambil keputusan untuk kelanjutan program kerja perusahaan.

Klasifikasi rasio keuangan berdasarkan sifatnya :

a) Rasio Likuiditas

Rasio likuiditas mengukur posisi likuiditas organisasi. Likuiditas berarti kemampuan untuk menutupi kewajiban jangka pendeknya. Kewajiban jangka pendek termasuk hutang tagihan, biaya terhutang, hutang bank dll. Rasio ini membandingkan antara jumlahuang tunai dengan hutang lancar. Adapun formula perhitungan rasio likuiditas adalah sebagai berikut :

\section{- Current Ratio}

Current ratio merupakan penghitungan rasio likuiditas untuk mengetahui tingkat kemampuan perusahaan dalam memenuhi kewajiban jangka pendeknya dengan aktiva perusahaan yang likuid pada saat ini atau aktiva lancar berbanding dengan hutang jangka pendeknya. 


$$
\mathrm{CR}=\frac{\text { ASET LANCAR }}{\text { HUTANG LANCAR }}
$$

Jika angka rasio lancar suatu perusahaan lebih dari 1,0 kali, maka perusahaan tersebut punya kemampuan yang baik dalam melunasi kewajibannya. Karena perbandingan aktivanya lebih besar dibanding kewajiban yang dimiliki.

- Quick Ratio

Quick ratio merupakan rasio yang mengukur kecepatan kemampuan perusahaan membayar hutang. Variabel pengukurannya adalah total aset cair terhadap total kewajiban lancar. Rasio cepat digunakan untuk mengukur posisi likuiditas, ketika stok (persediaan) diragukan.

$$
\mathrm{QR}=\frac{\text { Asset Lancar }- \text { Persediaan }}{\text { Hutang Lancar }}
$$

b) Rasio Profitabilitas

Rasio profitabilitas mengukur posisi profitabilitas yaitu kemampuan untuk memperoleh keuntungan. Hasil rasio menunjukkan laba yang dihasilkan dibandingkan dengan modal dalam bentuk persen. Lebih tinggi rasionya maka kemampuan perusahaan dalam menghasilkan laba lebih baik. Semakin tinggi rasio profitabilitas (GPM, OPM, NPM), semakin tinggi pula posisi profitabilitas perusahaan organisasi terkait. Adapun formula perhitungan rasio profitabilitas adalah sebagai berikut :

- Net Profit Margin

Marjin laba bersih (net profit margin) merupakan rasio untuk menilai persentase laba bersih yang didapat setelah dikurangi pajak terhadap pendapatan yang diperoleh dari penjualan. Rasio ini mengukur laba bersih setelah pajak terhadap penjualan.

$\mathrm{NPM}=\frac{\text { LABA BERSIH SETELAH PAJAK }}{\text { PENJUALAN }} \times 100 \%$

- Return On Asset

ROA (Return on Assets Ratio) merupakan rasio profitabilitas yang menunjukkan persentase keuntungan yang diperoleh perusahaan sehubungan dengan keseluruhan sumber daya atau total aset.

$\mathrm{ROA}=\frac{\text { LABA BERSIH SETELAH PAJAK }}{\text { TOTAL ASET }} \times 100 \%$

\section{- Return On Equity}

ROE (Return on Equity Ratio) merupakan rasio profitabilitas yang menunjukkan persentase keuntungan yang diperoleh dari penggunaan seluruh ekuitas atau modal yang dimilikinya.

$$
\mathrm{ROE}=\frac{\text { LABA BERSIH SETELAH PAJAK }}{\text { TOTAL EKUITAS }} \times 100 \%
$$

c) Rasio Solvabilitas 
Rasio solvabilitas mengukur posisi solvabilitas organisasi. Solvabilitas artinya kemampuan untuk memenuhi kewajiban jangka panjang. Kewajiban jangka panjang termasuk pembayaran pinjaman, pembayaran hutang yaitu bunga pembayaran dll.

\section{- Debt Equity Ratio}

Rasio hutang terhadap ekuitas (DER) ini menunjukkan hubungan antara jumlah hutang jangka panjang dengan jumlah modal yang dimiliki perusahaan. Rasio ini berguna untuk mengetahui jumlah dana yang disediakan kreditur dengan pemilik perusahaan.

DER $=\frac{\text { TOTAL HUTANG }}{\text { TOTAL EKUITAS }}$

- Equty Multiplier

Equity multiplier menunjukkan besaran porsi dari aktiva yang dibiayai oleh kreditur.

$\mathrm{EM}=\frac{\text { TOTAL AKTIVA }}{\text { TOTAL EKUITAS }}$

\section{- Capital Structure}

Struktur modal menunjukkan perbandingan antara hutang jangka panjang dengan total ekuitas sebagai komposisi modal yang diigunakan oleh perusahaan.

$\mathrm{CS}=\frac{\text { HUT ANG JANGKA PANJANG }}{\text { TOTAL EKUITAS }}$

d) Rasio Aktivitas

Rasio perputaran atau aktivitas mengukur posisi pemanfaatan sumber daya. Rasio perputaran yang lebih tinggi menunjukkan lebih baik pemanfaatan sumber daya. Sumber daya termasuk aset tetap, aset lancar, modal kerja, dll. Adapun formula perhitungan rasio perputaran adalah sebagai berikut :

- Inventory Turnover

Rasio ini merupakan perbandingan kemampuan dana pada persediaan yang berputar dalam satu periode tertentu. Perusahaan dapat melihat modal yang ada pada persediaan karena efisiensi pemakaian persediaan barang.

INVT TO $=\frac{\text { PENJUALAN }}{\text { PERSEDIAAN }}$

- Receivable Turnover

Rasio perputaran dihitung dengan membandingkan penjualan kredit dengan pihutang rata-rata. Semakin tinggi rasionya artinya modal kerja yang ditanamkan dalam pihutang semakin rendah, namun sebaliknya jika rasionya rendah maka ada over investment pada pihutang.

RCVBL TO $=\frac{\text { PENJUALAN }}{\text { PIUTANG }}$

- Total Asset Turnover 
Assets Turnover merupakan perbandingan antara penjualan bersih dengan total aktiva suatu perusahaan dalam satu periode. Semakin besar rasionya maka semakin baik pula kinerja perusahaan.

TATO $=\frac{P E N J U A L A N}{\text { TOTAL AKTIVA }}$

e) Dupont

Formula yang menunjukkan bahwa tingkat pengembalian tentang ekuitas dapat ditemukan sebagai produk dari net profit margin, total asset turnover, dan equity multiplier. Ini menunjukkan hubungan antar manajemen aset, hutang manajemen, dan profitabilitas rasio.

$$
\text { Dupont }=N P M \times T A T O \times E M
$$

\section{METODE PENELITIAN}

Jenis penelitian dalam karya tulis ini adalah penelitian komparatif, yaitu membandingkan kinerja dari PT.Summarecon Agung, Tbk dengan total perusahaan lain di industrinya yang terdaftar di Bursa Efek Indonesia. Dalam hal ini dilakukan analisis komparasi dengan studi kasus total industri property \& real estate dengan studi kasus emiten SMRA, CTRA dan JRPT dengan periode 2014-2019.

Metode analisis yang digunakan adalah deskriptif kuantitatif, yaitu analisis yang berdasarkan pada kuantitatif perhitungan untuk mengetahui kinerja perusahaan yang diukur dari laporan keuangan sebagai dasar atas pengambilan kebijakan.

Sumber data berasal dari data sekunder yaitu laporan keuangan dengan batasan lingkup tahun dari 2014 sampai 2019. Data dikumpulkan dengan metode studi dokumentasi. Data laporan keuangan bersumber dari laman web masing-masing perusahaan karena sudah terdaftar di Bursa Efek Indonesia sebagai perusahaan go public.

Lingkup objek penelitisan analisis komparatif rasio keuangan ada pada rasio likuiditas, rasio aktivitas, rasio profitabilitas dan rasio solvabilitas.

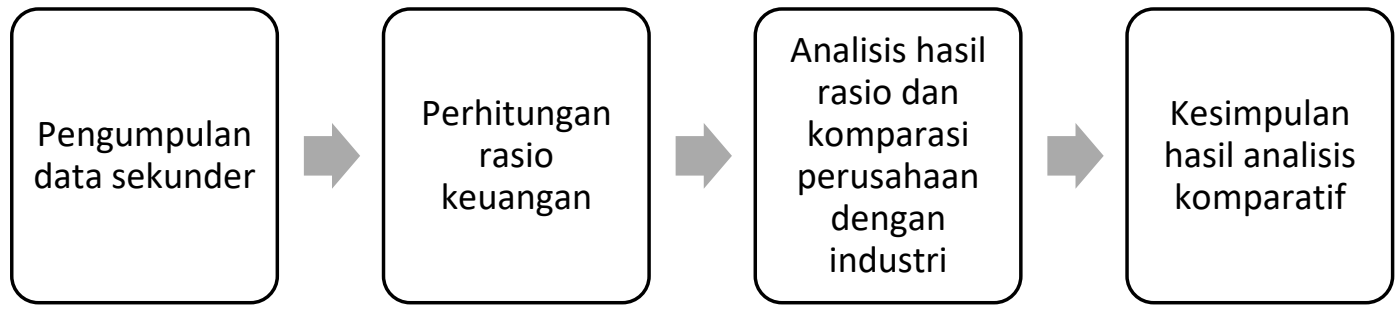

Gambar 3.1 Alur Penelitian

Teknik dan alur penelitian dimulai dengan pengumpulan data sekunder. Lalu dibuatkan perhitungan rasio keuangannya. Hasil perhitungan rasio didapatkan lalu dibuatkan grafik sebagai visualisasi pembanding perusahaan dengan industinya dan dianalisis perbandingan Dupont dari data yang didapatkan sebelumnya. Setelah itu dilakukan kesimpulan dari hasil penelitian yang telah dilakukan.

\section{HASIL DAN PEMBAHASAN}

Tabel 4. 1 Rasio Keuangan PT. Summarecon Agung, TBK \& Total Industri 2014-2019 


\begin{tabular}{|c|c|c|c|c|c|c|c|c|c|c|c|c|c|}
\hline \multirow{2}{*}{$\begin{array}{l}\text { JENIS } \\
\text { RASIO }\end{array}$} & \multirow{2}{*}{ FORMULA } & \multicolumn{2}{|c|}{2014} & \multicolumn{2}{|c|}{2015} & \multicolumn{2}{|c|}{2016} & \multicolumn{2}{|c|}{2017} & \multicolumn{2}{|c|}{2018} & \multicolumn{2}{|c|}{2019} \\
\hline & & SMRA & IND & SMRA & IND & SMRA & IND & SMRA & IND & SMRA & IND & SMRA & IND \\
\hline \multicolumn{14}{|c|}{ RASIO LIKUIDITAS } \\
\hline \multirow{2}{*}{$\begin{array}{l}\text { CURRENT } \\
\text { RATIO }\end{array}$} & $\begin{array}{l}\text { AKTIVA } \\
\text { LANCAR }\end{array}$ & \multirow{2}{*}{1.15} & \multirow{2}{*}{2.17} & \multirow{2}{*}{1.37} & \multirow{2}{*}{1.30} & \multirow{2}{*}{1.65} & \multirow{2}{*}{1.48} & \multirow{2}{*}{1.65} & \multirow{2}{*}{1.74} & \multirow{2}{*}{1.65} & \multirow{2}{*}{1.62} & \multirow{2}{*}{1.65} & \multirow{2}{*}{1.63} \\
\hline & $\begin{array}{l}\text { HUTANG } \\
\text { LANCAR }\end{array}$ & & & & & & & & & & & & \\
\hline \multirow{2}{*}{$\begin{array}{l}\text { QUICK } \\
\text { RATIO }\end{array}$} & $\begin{array}{c}\text { AKTIVA } \\
\text { LANCAR- } \\
\text { PERSEDIAAN }\end{array}$ & \multirow[t]{2}{*}{0.30} & \multirow[t]{2}{*}{0.90} & \multirow[t]{2}{*}{0.59} & 0.54 & 0.54 & 0.52 & 0.75 & 0.65 & 0.42 & 0.54 & 0.36 & 0.54 \\
\hline & $\begin{array}{l}\text { HUTANG } \\
\text { LANCAR } \\
\end{array}$ & & & & & & & & & & & & \\
\hline & & & & RAs & O SOL & ABILIT & & & & & & & \\
\hline $\begin{array}{l}\text { TOTAL } \\
\text { DEBT }\end{array}$ & $\begin{array}{c}\text { TOT AKTIVA } \\
\text { - TOT } \\
\text { EKUITAS }\end{array}$ & 0.34 & 0.51 & 0.61 & 0.55 & 0.34 & 0.55 & 0.61 & 0.53 & 0.61 & 0.53 & 0.61 & 0.53 \\
\hline & TOT AKTIVA & & & & & & & & & & & & \\
\hline DEBT & $\begin{array}{c}\text { TOT } \\
\text { HUTANG } \\
\end{array}$ & & & & & & & & & & & & \\
\hline RATIO & $\begin{array}{c}\text { TOT } \\
\text { EKUITAS } \\
\end{array}$ & 0.46 & 0.47 & 0.67 & 0.72 & 0.59 & 0.62 & 0.52 & 0.53 & 0.75 & 0.58 & 0.80 & 0.58 \\
\hline EQUITY & TOT AKTIVA & & & & & & & & & & & & \\
\hline $\begin{array}{l}\text { MULTIPLI } \\
\text { ER }\end{array}$ & $\begin{array}{c}\text { TOT } \\
\text { EKUITAS } \\
\end{array}$ & 1.51 & 2.04 & 2.57 & 2.20 & 2.49 & 2.13 & 2.55 & 2.13 & 2.59 & 2.11 & 2.57 & 2.10 \\
\hline $\begin{array}{l}\text { CAPITAL } \\
\text { STRUCTU }\end{array}$ & $\begin{array}{l}\text { HUTANG } \\
\text { JANGKA } \\
\text { PANJANG }\end{array}$ & 0.05 & 0.57 & 0.90 & 0.48 & 0.91 & 0.50 & 1.03 & 0.60 & 0.78 & 0.53 & 0.77 & 0.53 \\
\hline $\mathrm{RE}$ & $\begin{array}{c}\text { TOT } \\
\text { EKUITAS } \\
\end{array}$ & & & & & & & & & & & & \\
\hline & & & & RA & IO PEF & UTAR & & & & & & & \\
\hline $\begin{array}{c}\text { RECEIVA } \\
\text { BLE }\end{array}$ & PENJUALAN & & & & & & & & & & & & \\
\hline $\begin{array}{c}\text { TURNOV } \\
\text { ER } \\
\end{array}$ & PIHUTANG & 24.81 & 2.86 & 62.37 & 11.27 & 36.99 & 9.93 & 9.83 & 6.26 & 8.54 & 5.71 & 12.45 & 5.05 \\
\hline $\begin{array}{l}\text { DAY'S } \\
\text { SALE }\end{array}$ & 365 HARI & & & & & & & & & & & & \\
\hline $\begin{array}{c}\text { TURNOV } \\
\text { ER }\end{array}$ & $\begin{array}{c}\text { RECEIVABLE } \\
\text { TURNOVER }\end{array}$ & 15 & 128 & 6 & 32 & 10 & 37 & 37 & 58 & 43 & 64 & 29 & 72 \\
\hline $\begin{array}{c}\text { INVENTO } \\
\text { RY }\end{array}$ & HPP & & & & & & & & & & & & \\
\hline $\begin{array}{c}\text { TURNOV } \\
\text { ER } \\
\end{array}$ & PERSEDIAAN & 0.36 & 0.36 & 0.82 & 0.57 & 0.55 & 0.50 & 0.51 & 0.45 & 0.47 & 0.40 & 0.37 & 0.39 \\
\hline $\begin{array}{l}\text { DAY'S } \\
\text { SALE IN }\end{array}$ & 365 HARI & & & & & & & & & & & & \\
\hline $\begin{array}{l}\text { INVENTO } \\
\text { RY }\end{array}$ & $\begin{array}{c}\text { INVENTORY } \\
\text { TURNOVER }\end{array}$ & 1016 & 1020 & 445 & 635 & 662 & 725 & 721 & 805 & 772 & 910 & 985 & 941 \\
\hline $\begin{array}{l}\text { TOTAL } \\
\text { ASSET }\end{array}$ & PENJUALAN & & & & & & & & & & & & \\
\hline $\begin{array}{c}\text { TURNOV } \\
\text { ER } \\
\end{array}$ & $\begin{array}{l}\text { TOTAL } \\
\text { ASSET }\end{array}$ & 0.22 & 0.21 & 0.35 & 0.30 & 0.30 & 0.29 & 0.26 & 0.25 & 0.26 & 0.23 & 0.24 & 0.23 \\
\hline & & & & RAS & $\mathrm{PROI}$ & TABILI & & & & & & & \\
\hline PROFIT & $\begin{array}{c}\text { LABA } \\
\text { BERSIH }\end{array}$ & $43 \%$ & $17 \%$ & $26 \%$ & $29 \%$ & $19 \%$ & $24 \%$ & $11 \%$ & $19 \%$ & $9 \%$ & $18 \%$ & $12 \%$ & 19 \\
\hline MARGIN & PENJUALAN & & & & & & & & & & & & $\%$ \\
\hline RETURN & $\begin{array}{c}\text { LABA } \\
\text { BERSIH }\end{array}$ & $9 \%$ & $40 \%$ & $0 \%$ & $0 \%$ & $6 \%$ & $7 \%$ & $3 \%$ & $5 \%$ & $3 \%$ & $4 \%$ & $3 \%$ & $40 \%$ \\
\hline ON ASSET & $\begin{array}{l}\text { TOTAL } \\
\text { ASSET }\end{array}$ & $9 \%$ & $4 \%$ & $9 \%$ & $9 \%$ & $0 \%$ & $1 \%$ & $3 \%$ & $5 \%$ & $3 \%$ & $4 \%$ & $3 \%$ & $4 \%$ \\
\hline $\begin{array}{c}\text { RETURN } \\
\text { ON }\end{array}$ & $\begin{array}{c}\text { LABA } \\
\text { BERSIH }\end{array}$ & $14 \%$ & $7 \%$ & $23 \%$ & $19 \%$ & $14 \%$ & $15 \%$ & $7 \%$ & $10 \%$ & $6 \%$ & $9 \%$ & $8 \%$ & $9 \%$ \\
\hline
\end{tabular}




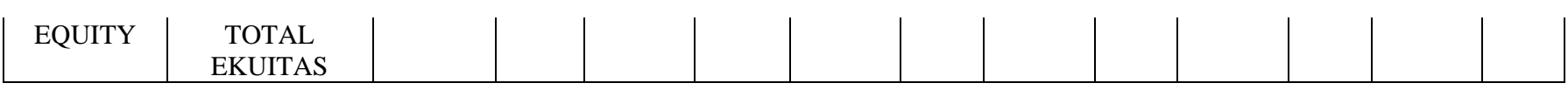

Sumber: Laporan Keuangan Tahunan PT. Summarecon Agung, Tbk \& Total Industri 20142019.

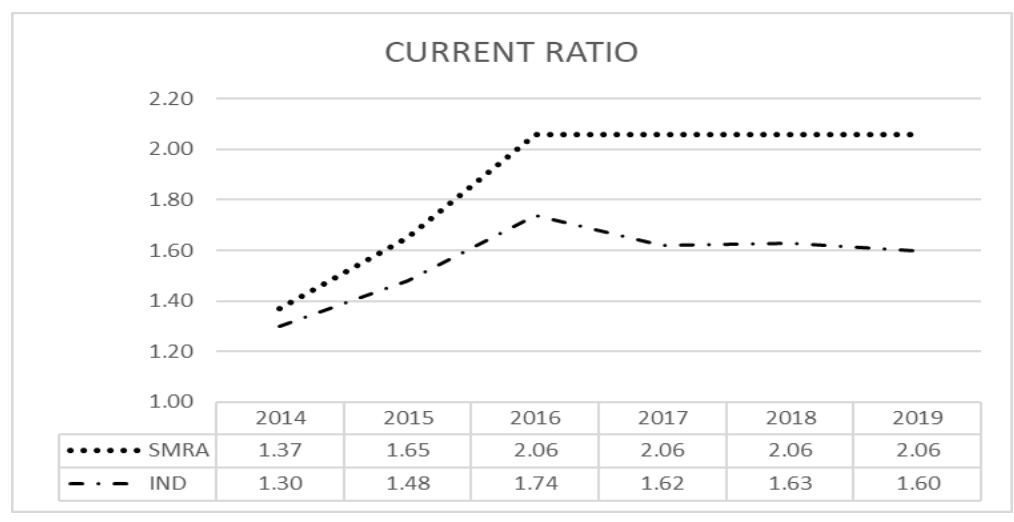

Grafik 4. 1 Grafik Perbandingan Current Ratio SMRA \& Industri

Current ratio dengan nilai $>1$ artinya mampu memenuhi segala kewajiban jangka pendeknya. Sebaliknya jika $<1$ maka tidak mampu memenuhi segala kewaajiban jangka pendeknya.

Perbandingan bervariasi . Hasil rata-rata current ratio SMRA 1,88 sedangkan pada industri 1,56. Sehingga dapat dilihat bahwa current ratio SMRA berada pada posisi di atas industri. Dapat disimpulkan SMRA lebih baik utk memenuhi segala kewajiban jangka pendek.

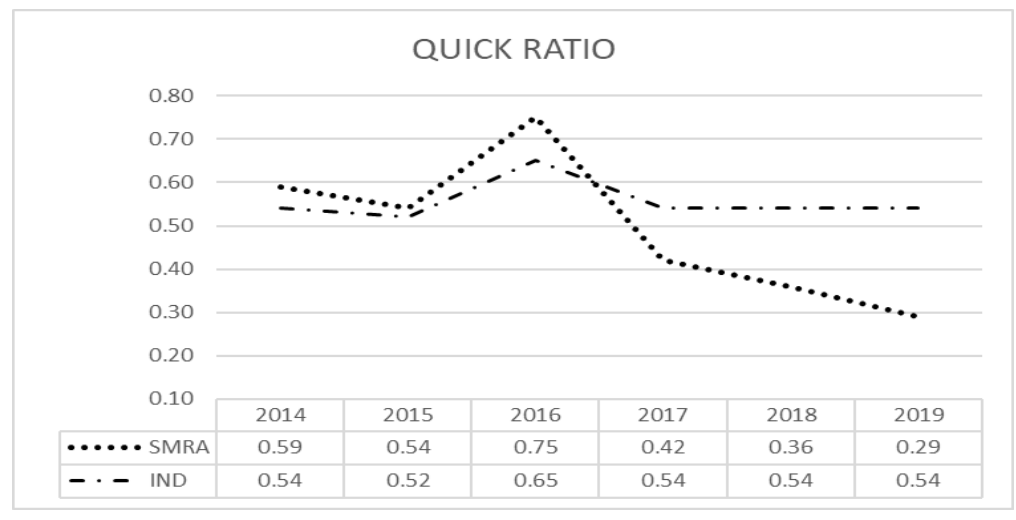

Grafik 4. 2 Grafik Perbandingan Quick Ratio SMRA \& Industri

Quick ratio dengan nilai > 1 artinya mampu memenuhi segala kewajiban jangka pendeknya dengan cepat. Sebaliknya jika $<1$ maka tidak mampu memenuhi segala kewaajiban jangka pendeknya dengan cepat.

Perbandingan bervariasi . Hasil rata-rata QR SMRA 0,49 sedangkan pada industri 0,56. Sehingga dapat dilihat bahwa QR SMRA berada posisi di bawah industri. Pada kondisi ini nilai rasio lancar yang lebih rendah daripada 1 mengindikasikan bahwa kemungkinan perusahaan berada dalam kesulitan posisi keuangan untuk memenuhi hutang lancarnya. Dapat disimpulkan industri lebih baik utk memenuhi segala kewajiban jangka pendek. 


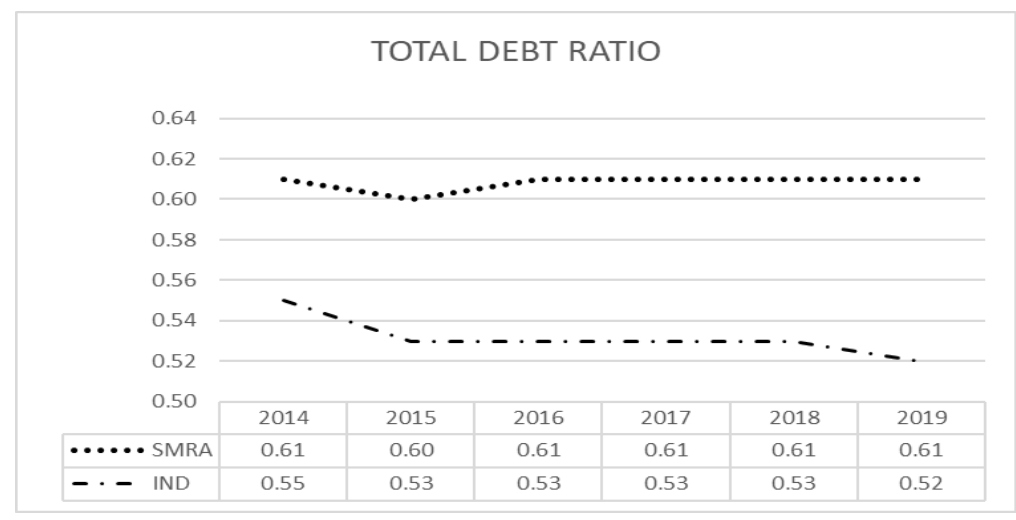

Grafik 4. 3 Grafik Perbandingan Debt Ratio SMRA \& Industri

Debt Ratio menunjukkan seberapa besar perusahaan bertumpu pada hutang untuk menjalankan operasional dan asset perusahaan. Bagi kreditur, rasio ini menunjukkan besar kecil nya risiko saat memberikan pinjaman. Semakin tinggi angka rasio maka risikonya pun semakin tinggi.

Perbandingan hampir linear dari tahun ke tahun . Hasil rata-rata DR SMRA 0,61 sedangkan pada industri 0,53. Sehingga dapat dilihat bahwa DR SMRA berada posisi di atas industri. Dapat disimpulkan industri lebih tidak berisiko apabila dilakukan peminjaman dana oleh kreditur.

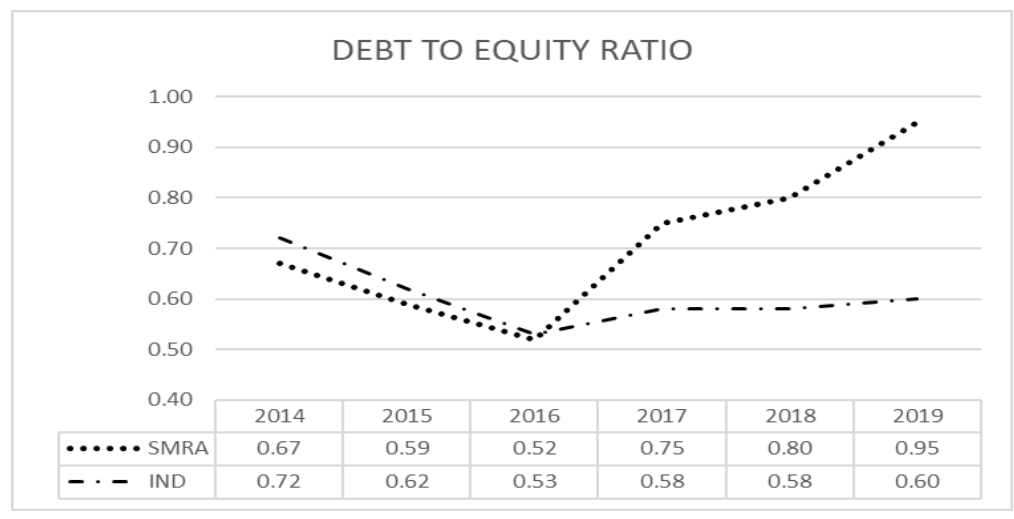

Grafik 4. 4 Grafik Perbandingan DER SMRA \& Industri

DER disebut sebagai rasio hutang modal yang menunjukkan porsi relatif antara ekuitas dan hutang yang dipakai untuk membiayai asset organisasi. Bagi kreditur, rasio ini menunjukkan besar kecil nya risiko saat memberikan pinjaman.

Perbandingan bervariasi dari tahun ke tahun . Hasil rata-rata DER SMRA 0,71 sedangkan pada industri 0,61. Sehingga dapat dilihat bahwa DER SMRA berada posisi di atas industri. Dapat disimpulkan industri lebih tidak berisiko apabila dilakukan peminjaman dana oleh kreditur. 


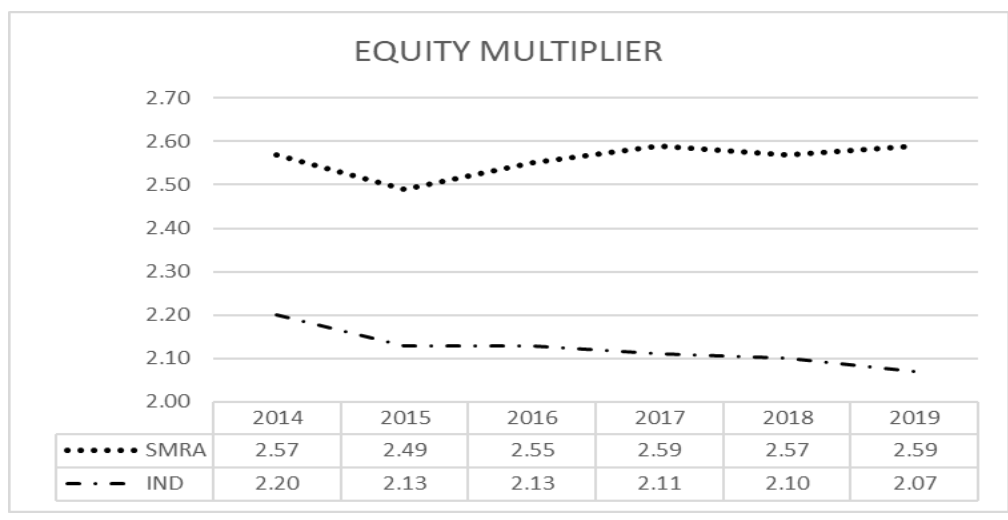

Grafik 4. 5 Grafik Perbandingan EM SMRA \& Industri

Equity multiplier diketahui juga sebagai financial leverage menunjukkan besaran porsi dari aktiva yang dibiayai oleh kreditur. Semakin besar rasio, maka semakin kecil pembiayaan oleh kreditur.

Perbandingan hampir linear dari tahun ke tahun . Hasil rata-rata EM SMRA 2,56 sedangkan pada industri 2,12. Sehingga dapat dilihat bahwa EM SMRA berada posisi di atas industri. Dapat disimpulkan bahwa SMRA memiliki porsi hutang yang lebih besar untuk membiayasi aktiva daripada industri.

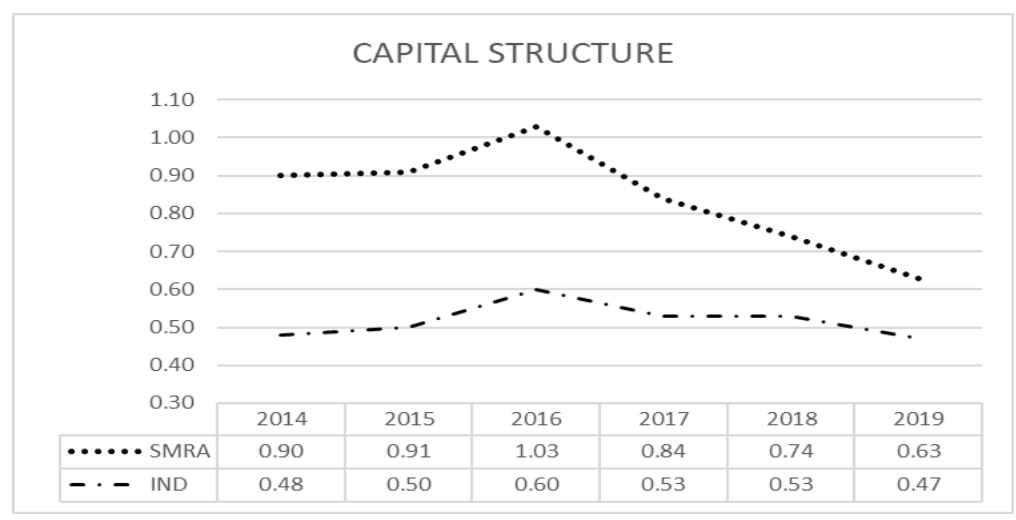

Grafik 4. 6 Grafik Perbandingan Capital Structure SMRA \& Industri

Capital Structure dikenal sebagai struktur modal, menunjukkan perbandingan antara hutang jangka panjanng dengan total ekuitas sebagai komposisi modal yang diigunakan oleh perusahaan Semakin tinggi angka rasio, maka hutang jangka panjang yang digunakan semakin besar.

Perbandingan bervariasi . Hasil rata-rata CS SMRA 0,84 sedangkan pada industri 0,52. Sehingga dapat dilihat bahwa CS SMRA berada posisi di atas industri. Dapat disimpulkan SMRA lebih besar pinjaman yang dipakai untuk pembiayaan modal perusahaan jika dibandingkan dengan industrinya dan termasuk ke dalam kategori low leverage karena proporsi hutangnya lebih rendah dibandingkan proporsi ekuitasnya. 


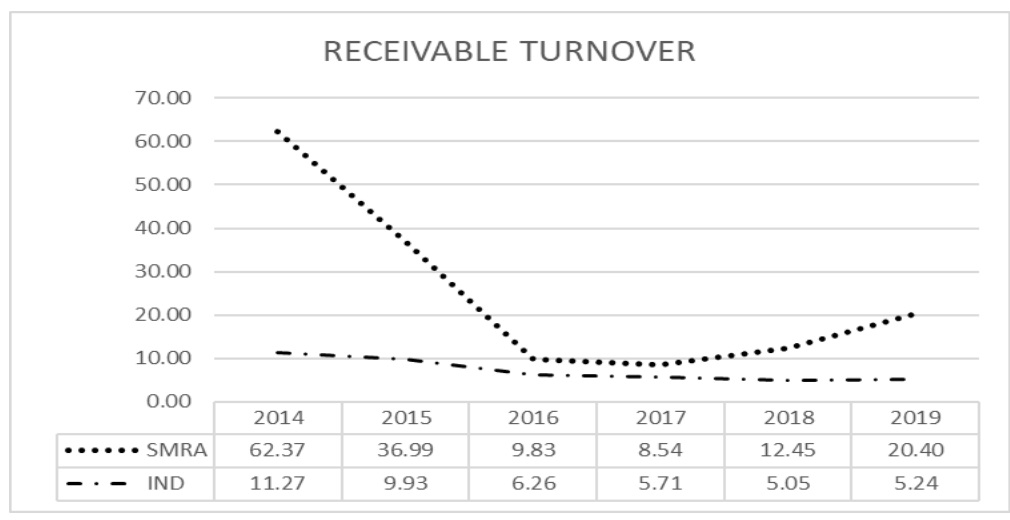

Grafik 4. 7 Grafik Perbandingan Receivable Turnover SMRA \& Industri

Menunjukkan efektifitas perputaran piutang. Semakin cepat perputaran piutang, maka semakin efektif perusahaan dalam pengelolaan piutangnya.

Perbandingan bervariasi. Hasil rata-rata receiveable turnover SMRA 25,1 sedangkan pada industri 7,24. Sehingga dapat dilihat bahwa receiveable turnover SMRA berada posisi di atas industri. Dapat disimpulkan SMRA lebih cepat perputaran piutangnya Dari rasio 25,1 mengindikasikan perusahaan dapat mengumpulkan piutang hampir setiap bulan sekali dalam satu tahun.

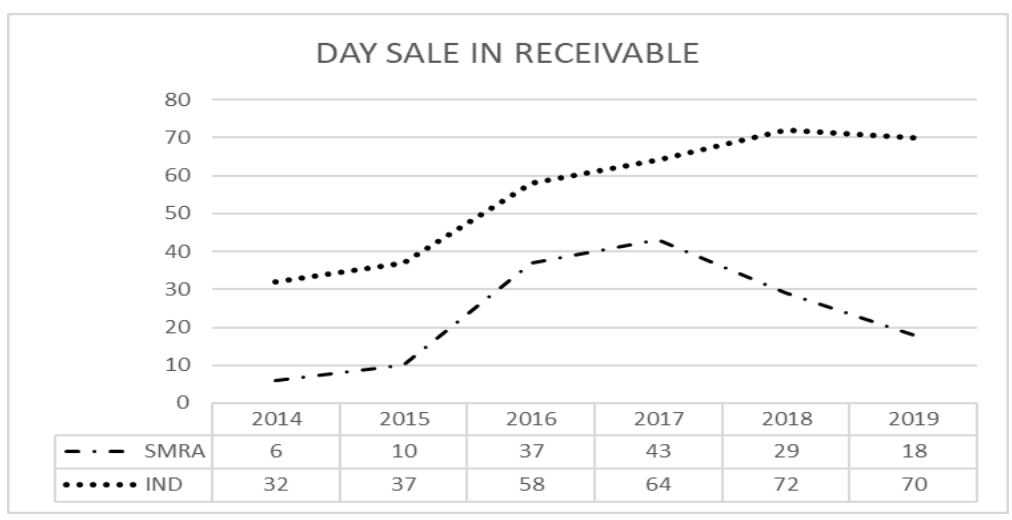

Grafik 4. 8 Grafik Perbandingan Day's Sale Receivable SMRA \& Industri

Disebut juga sebagai average collection, menunjukkan rata rata berapa hari perusahaan mendapatkan piutang terbayar. Semakin cepat piutang terbayar, kas perusahaan semakin baik.

Perbandingan bervariasi . Hasil rata-rata SMRA 24 hari sedangkan pada industri 56 hari. Sehingga dapat dilihat bahwa SMRA berada posisi di bawah industri. Dapat disimpulkan SMRA lebih cepat terbayarnya pihutang dan mengindikasikan kas perusahaan lebih baik. 


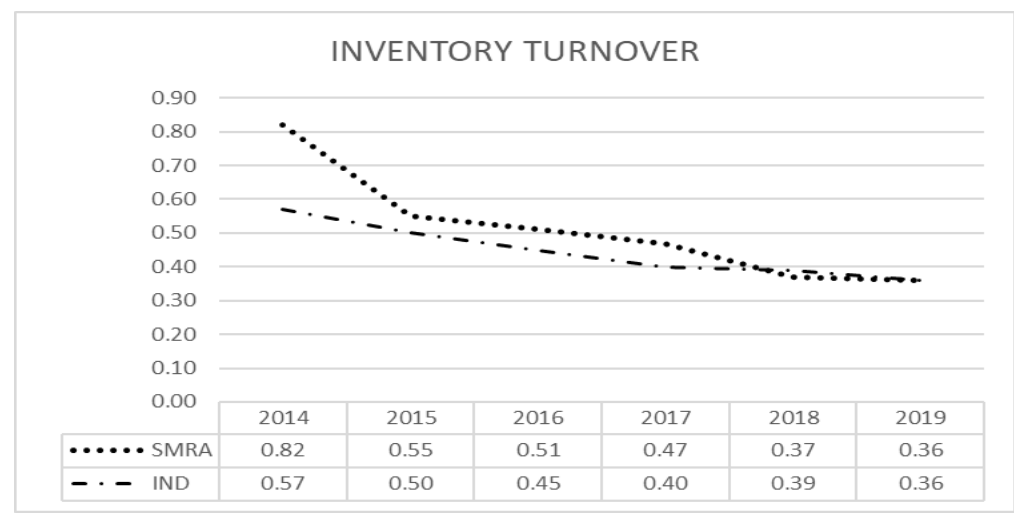

Grafik 4. 9 Grafik Perbandingan Inventory Turnover SMRA \& Industri

Rasio efisiensi yang menunjukkan seberapa efektif persediaan dikelola dengan membandingkan harga pokok penjualan dengan persediaan rata-rata untuk satu periode. Semakin besar rasio maka semakin cepat perusahaan dalam menjual persediaan.

Perbandingan hampir linear untuk keduanya . Hasil rata-rata SMRA 0,51 sedangkan pada industri 0,45. Sehingga dapat disimpulkan bahwa SMRA berada posisi di atas industri. Dapat disimpulkan industri lebih baik dalam menjual persediaan.

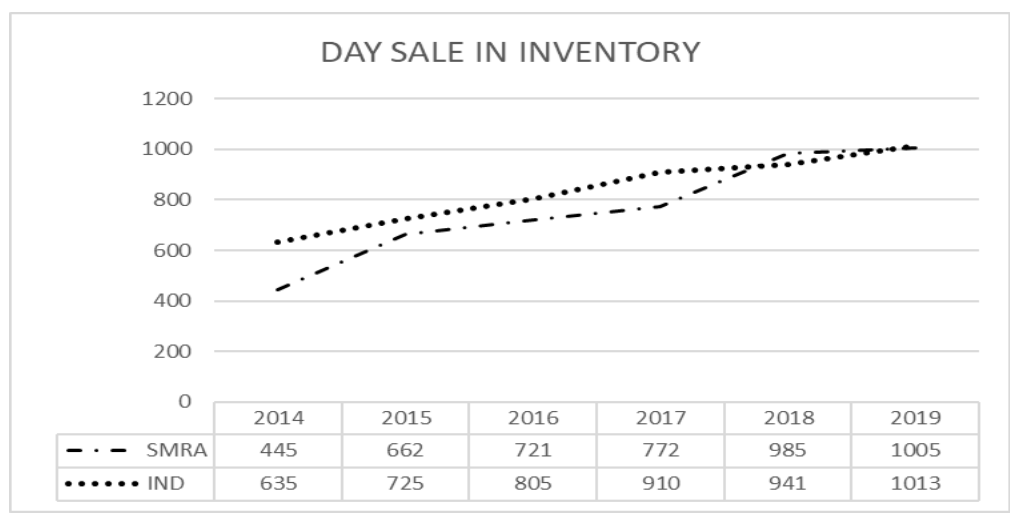

Grafik 4. 10 Grafik Perbandingan Day's Sale Inventory SMRA \& Industri

Menunjukkan rata rata berapa hari perusahaan dapat menjual persediaan. Semakin cepat persediaan terjual, maka kas perusahaan semakin baik.

Perbandingan hampir linear untuk keduanya. Hasil rata-rata SMRA 765 hari sedangkan pada industri 838 hari. Sehingga hasil akhir rata rata menunjukkan SMRA berada posisi di bawah industri. Dapat disimpulkan SMRA lebih cepat penjualan persediaannya dan mengindikasikan kas perusahaan lebih baik. 


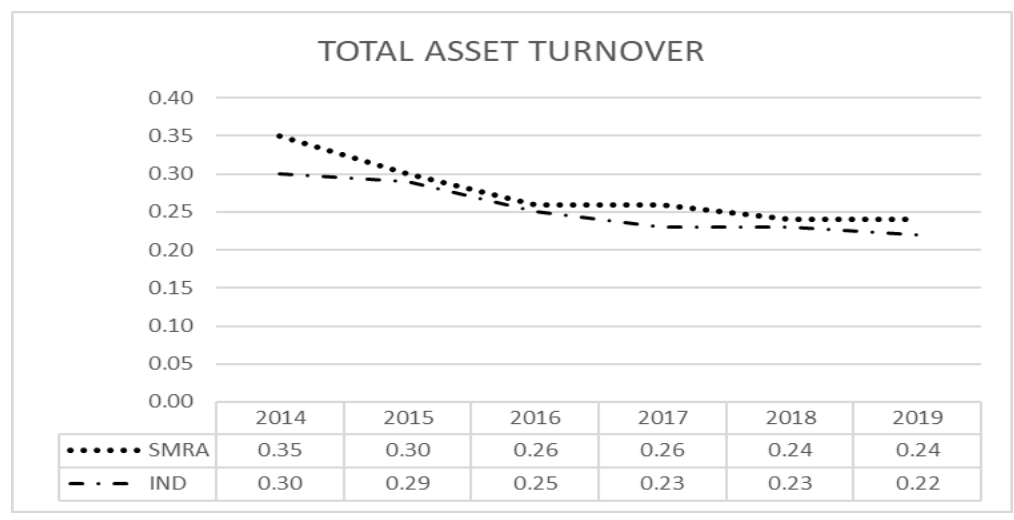

Grafik 4. 11 Grafik Perbandingan TATO SMRA \& Industri

Rasio ini menjunjukan sejauh mana efektifitas perusahaan dalam mengelola assetnya dalam menghasilkan penjualan.Semakin tinggi rasio menunjukkan efektifitasnya dalam mengelola asset semakin baik.

Perbandingan hampir linear untuk keduanya. Hasil rata-rata SMRA 0,28 sedangkan pada industri 0,25 hari. Sehingga hasil akhir rata rata menunjukkan SMRA berada posisi di atas industri. Dapat disimpulkan SMRA lebih efektif dalam pengelolaan assetnya.

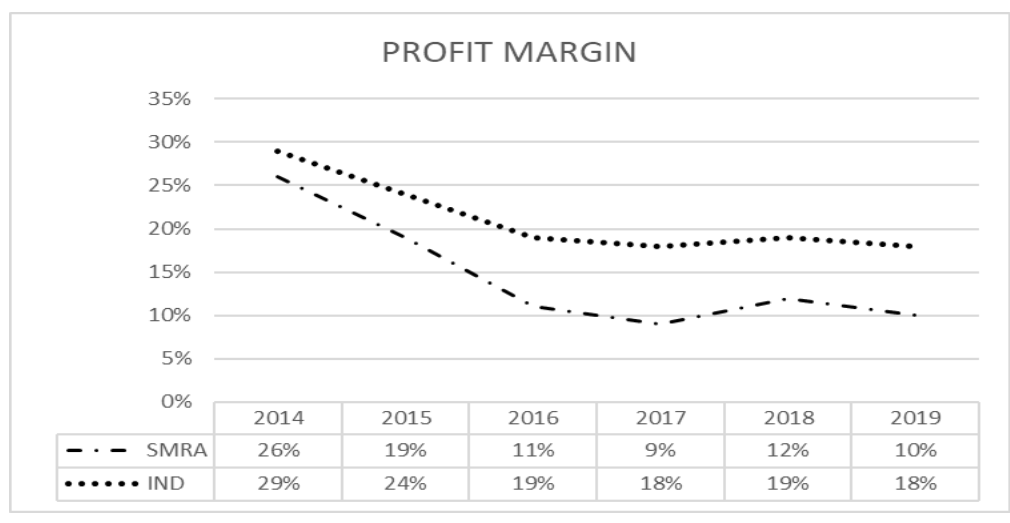

Grafik 4. 12 Grafik Perbandingan Profit Margin SMRA \& Industri

Indikator dalam menunjukkan rasio dari laba bersih dengan pendapatan. Semakin tinggi rasionya maka semakin baik perusahaan dalam menghasilkan laba.

Perbandingan bervariasi. Hasil rata-rata SMRA 15\% sedangkan pada industri $21 \%$. Sehingga hasil akhir rata rata menunjukkan SMRA berada posisi di bawah industri. Dapat disimpulkan industri lebih baik dalam presentase laba dibandingkan SMRA.

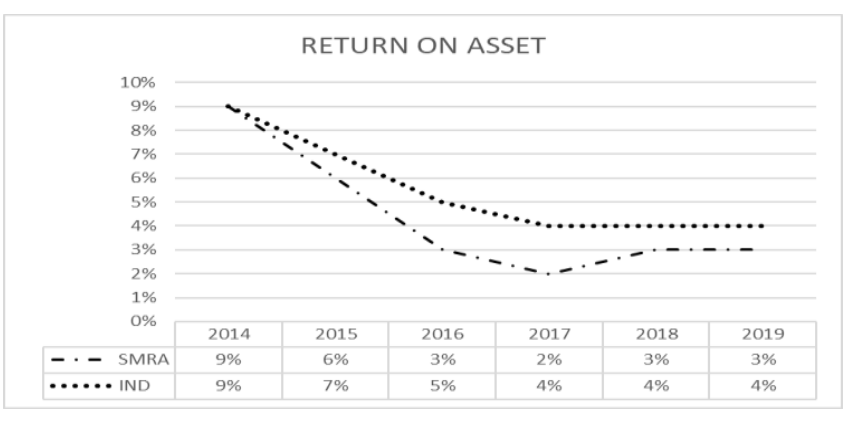

Grafik 4. 13 Grafik Perbandingan ROA SMRA \& Industri 
Menunjukkan kemampuan perusahaan dalam menghasilkan laba dari penggunaan seluruh sumber daya atau asset yang dimilikinya. Semakin tinggi rasionya maka semakin baik. Perbandingan bervariasi . Hasil rata-rata SMRA 4\% sedangkan pada industri 5\%. Sehingga hasil akhir rata rata menunjukkan SMRA berada posisi di bawah industri. Dapat disimpulkan industri lebih baik dalam presentase menghasilkan laba dari penggunaan asset dibandingkan SMRA.

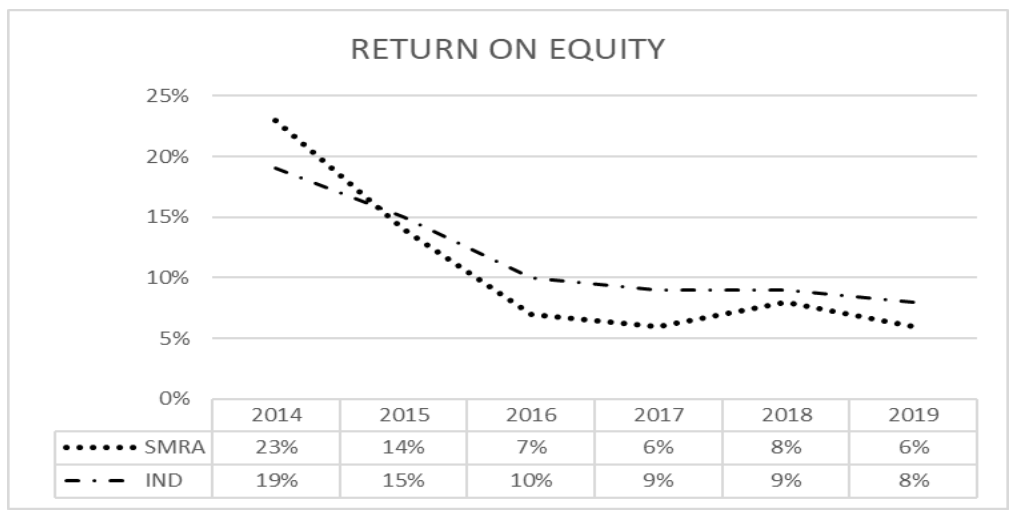

Grafik 4. 14 Grafik Perbandingan ROE SMRA \& Industri

Menunjukkan kemampuan perusahaan dalam menghasilkan laba dari penggunaan seluruh ekuitas atau modal yang dimilikinya. Semakin tinggi rasionya maka semakin baik.

Perbandingan bervariasi . Hasil rata-rata SMRA 11\% sedangkan pada industri $12 \%$. Sehingga hasil akhir rata rata menunjukkan SMRA berada posisi di bawah industri. Dapat disimpulkan industri lebih baik dalam presentase menghasilkan laba dari penggunaan ekuitas dibandingkan SMRA.

Tabel 4. 2 Tabel Dupont PT.Summarecon Agung,Tbk dan Total Industri

\begin{tabular}{|r|r|r|r|r|r|r|r|r|}
\hline & \multicolumn{2}{|c|}{ PM } & \multicolumn{2}{c|}{ TATO } & \multicolumn{2}{c|}{ EM } & \multicolumn{2}{c|}{ DUPONT } \\
\hline & SMRA & IND & SMRA & IND & SMRA & IND & SMRA & \multicolumn{1}{c|}{ IND } \\
\hline 2014 & $26 \%$ & $29 \%$ & 0.35 & 0.30 & 2.57 & 2.20 & $23.4 \%$ & $19.1 \%$ \\
\hline 2015 & $19 \%$ & $24 \%$ & 0.30 & 0.29 & 2.49 & 2.13 & $14.2 \%$ & $14.8 \%$ \\
\hline 2016 & $11 \%$ & $19 \%$ & 0.26 & 0.25 & 2.55 & 2.13 & $7.3 \%$ & $10.1 \%$ \\
\hline 2017 & $9 \%$ & $18 \%$ & 0.26 & 0.23 & 2.59 & 2.11 & $6.1 \%$ & $8.7 \%$ \\
\hline 2018 & $12 \%$ & $19 \%$ & 0.24 & 0.23 & 2.57 & 2.10 & $7.4 \%$ & $9.2 \%$ \\
\hline 2019 & $10 \%$ & $18 \%$ & 0.24 & 0.22 & 2.59 & 2.07 & $6.2 \%$ & $8.2 \%$ \\
\hline
\end{tabular}

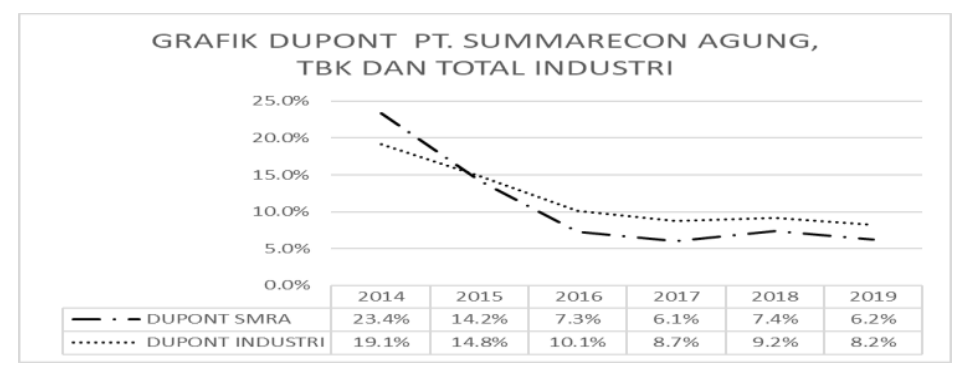

Grafik 4. 15 Grafik Perbandingan Dupont SMRA dan total industri Prop \& Real Estate

Dapat terlihat dari grafik dan di atas yang menunjukkan perbandingan bervariasi . Hasil rata-rata SMRA 10,8\% sedangkan pada industri 11,7\%. Sehingga hasil akhir rata rata menunjukkan SMRA berada posisi di bawah industri. Dapat disimpulkan industri lebih baik dibandingkan SMRA. 


\section{KESIMPULAN DAN SARAN}

Perhitungan analisis rasio keuangan dapat menggambarkan kinerja perusahaan sehingga dapat menjadi alat untuk pengambilan kebijakan oleh manajemen perusahaan. Untuk analisis komparasi rasio keuangan PT.Summarecon Agung,Tbk dengn total industri property \& real estate yang terdaftar di BEI (studi kasus emiten CTRA \& JRPT) adalah sebagai berikut :

PT.Summarecon Agung,Tbk mengalami penurunan laba cukup jauh dari 2014 hingga 2017 lalu naik lagi di 2018 dan mengalami penurunan 2\% di 2019. Pergerakan leverage menurun dari 2014 ke 2015 dan naik kembali pada 2019 hingga nilai leverage 2019 lebih tinggi dari 2014. Perubahan penurunan margin keuntungan dan penambahan asset. Investor juga dapat menarik kesimpulan bahwa PT.Summarecon Agung,Tbk juga menambahkan hutangnya dalam total asset karena rata-rata ekuitas tetap sama.

Sementara itu, pada total industri, penurunan laba berlaku juga setiap tahunnya. Investor dapat melihat bahwa seluruh perubahan ROE disebabkan oleh penurunan leverage keuangan. Ini berarti industri meminjam lebih banyak uang, tetapi nilai ekuitas turut menaik cukup jauh. Sementara itu, hutang tambahan dinilai tidak mengubah profit margin perusahaan, sehingga hal ini menandakan bahwa leverage tidak menambah nilai riil bagi perusahaan.

Atas dasar hasil Dupont Analysis, dapat disimpulkan bahwa kinerja keduanya hampir sama efektifitasnya dilihat dari hasil nilai Dupont untuk PT.Summarecon Agung,Tbk 10,8\% dan industri $11,7 \%$. Hasil akhir rata rata menunjukkan SMRA berada posisi di bawah industri tetapi tidak terpaut jauh hanya selisih $0,9 \%$.

\section{DAFTAR RUJUKAN}

Brigham, Eugene F \& Joel F. Houston (2018) Fundamental Of Financial Management 15th Edition. Boston:Cengage Learning.

Manuhutu, Yana Aprilia, Herman Karamoy \& Sintje Rondonuwu (2020) Analisis Laporan Keuangan Untuk Mengukur Kinerja Keuangan Perusahaan Telekomunikasi Pt. Smartfren Telecom Tbk Tahun 2017-2018. Vol.15(2);55-61.

Rabuisa, Wilna Feronika, Treesje Runtu Dan Heince Wokas (2018) Analisis Laporan Keuangan Dalam Menilai Kinerja Keuangan Perusahaan Pada Bank Perkreditan Rakyat (Bpr) Dana Raya Manado. Vol.13(2) ; 325-333.

Ross, Stephen A, Randolph W. Westerfield \& Bradford D. Jordan (2007) Essentials Of Corporate Finance. New York:Mcgraw Hill.

Satria, Ilham.(2016) Modul Akuntansi Keuangan 1. Aceh: Universitas Malikussaleh.

Singh, Y.P (2007) Accounting And Financial Management. New Delhi:New Age International Limited Publisher.

Syaifuddin, Dedy Takdir (2008) Manajemen Keuangan Teori Dan Aplikasi. Kendari: Universitas Haluleo 